\title{
PROPOSING A THEORETICAL FRAMEWORK FOR LOCAL TERRITORIAL IDENTITIES: CONCEPTS, QUESTIONS AND PITFALLS
}

\author{
Tiziana BANINI \\ Sapienza University of Rome, Rome, Department of Document Studies, Linguistics, Philology and Geography, ITALY \\ tiziana.banini@uniroma1.it
}

DOI: http://doi.org/10.23740/TID220172

\section{ABSTRACT}

When local territorial identity is understood as closely linked to sustainable, participatory and place-based development issues, it can become a dynamic, open, and plural social construction process, through which collectivities/groups choose the distinctive characteristics of the territory they inhabit, in order to develop shared views and common targets for policy implementation.

In this sense, territorial identity is not to be 'unveiled' or 'discovered', but 'built' through a research-action focused on the opinions, attitudes, and expectations of local collectivities towards the territory they live or act in.

As a research topic, local territorial identity is far from easy to deal with. Based on the key issues raised during the works of the national research group "Territorial Identities" of A.Ge.I. (Association of Italian Geographers), founded in 2008 , the contribution aims at presenting some theoretical and methodological questions and pitfalls in studying territorial identities, proposing some possible answers.

Keywords: local territorial identity, territorialist approach, participative processes, place consciousness, active inhabiting

\section{INTRODUCTION}

In the everyday language, as well as in the political and institutional arena, territorial identity is an expression largely used, thanks to its strong evocative and performative power. The geographic debate has highlighted on several occasions the limits and the risks that territorial identities discourses carry with them, including those related to political instrumentation and spatial fetishism (Paasi, 2003; Guermond, 2006; Di Meo, 2016).

Treated in unproblematic and taken-for-granted terms, territorial identity is often considered as an intrinsic quality of the territory, stable, fixed, independent from human action, as 'something' that territories 'have' or 'do not have', for better or for worse.

In these cases, there is the risk of falling into essentialist conceptions of territorial identity that ascribe some connotations to territories on the basis of reified discourses, stereotypes or habits, without considering some key questions: Territorial identity according to whom? By which criteria? And for what purposes? That is, without considering the relational, socially constructed and historically contingent nature of all identities, not only social and cultural, but territorial as well. In other words, without considering that territory is not the container of 
things and subjects (or rather, an absolute space where events happen and things are located), but the content of relations (Law \& Mol, 1994), territory is a relational space. In this sense, the 'territorial' and the 'relational' perspectives can be seen no more as opposite ontological realms, but in their traversing and interrelated characters (Paasi \& Metzger, 2017, p. 23).

Territorial identity and related matters are topics largely explored at a national and regional (both subnational and supernational) scale, mainly through a political-economic perspective (Paasi, 2009; Antonsich, 2014; de Wit, 2012). From 2013, the national research group "Territorial Identities" of A.Ge.I. (Association of Italian Geographers), of which I am coordinator, has instead began to focus on the local scale, that is to say on contexts of small physical and demographic dimensions (from an urban neighborhood to an aggregate of a few municipalities), where the physical proximity between the inhabitants - although compromised by contemporary life practices - can potentially promote the temporal continuity of social relationships with and for the territory, becoming a common reason for collective shared actions, initiatives, and projects. A way of considering the "local", then, very similar to the notion of locale (Agnew, 1987) or locality (Taylor, 1982; Clarke \& Kirby, 1990), understood as the physical setting where people's daily practices and experiences unfold.

The A.Ge.I. research group "Territorial Identities" preferred the local scale, as above defined, for two main reasons: first, because local is the scale where international political priorities (sustainability, production of cultural specificity, participation in decision-making processes, etc.) can be socially implemented; second, because local is also the scale where people's knowledge, memories, values, experiences, practices make territory a space of both collective significance and possible shared social action.

This contribution focuses only on some key theoretical and methodological questions which raised during the research group's works, whose contributions have been published on four editorial occasions (for bibliographic references, see Banini, 2013; Banini \& Pollice, 2015), postponing a more articulate discussion of the topic on another occasion. In particular, after having synthetically defined the notion of territorial identity according to a territorialist perspective, I will focus on some preliminary questions and pitfalls, then I will conclude with some remarks.

\section{DEFINING LOCAL TERRITORIAL IDENTITY}

The notion of 'active territoriality', in the French-Italian geographic literature, stands for a dynamic and open social construction of the territory, "from below" (actors, groups, individuals), and not only "from above", that is to say by institutional, political and decisionmaking actors, as in the prevailing Anglo-American idea of territory and territoriality (Governa \& Salone, 2004; Governa, 2006; Elden, 2010).

The idea of 'active territoriality' has been utilized, in the first half of the 2000s, for the notion of SLoT - Sistema Locale Territoriale (Local Territorial System), a theoretical and operative model based on the creation of a voluntary local actors network (entrepreneurs, associations, institutions, etc.), aimed at elaborating and realizing a common project, mainly an economic project (Dematteis \& Governa, 2005).

The A.Ge.I. research group "Territorial Identities" has instead proposed an idea of 'active territoriality' socially declined, that is to say extended to the entire population inhabiting a 
local context and related to the ordinary life of the territory. In our case, therefore, the notion of territory as social construction foreshadows the possibility for local population to act as a collective actor for the pursuing of territorial shared aims, from the creation of a citizens' network engaged in local food chains, in social care services or in public green management, to the formation of a collective subject finalized at the participation to local decision-making processes. This goal is far more relevant to achieve when 'active territoriality' is based on the so-called place consciousness, that Magnaghi (2010, p. 133) defines as the "awareness of the value of the territorial common goods as essential elements for the reproduction of individual and collective life, as much as biological and cultural life".

In other words, in the French-Italian territorialist perspective, whose theoretical origins can be traced back to Claude Raffestin (1980) and Angelo Turco (1988), territoriality can be defined as a responsible, active and participatory way of inhabiting places, so that territorial identity can be considered as a practice of 'active territoriality', aware of the material and relational value of the territory, directed to the well-being of both local collectivities and ecosystems, and theoretically situated between the socio-constructivist approaches and the humanistic/existentialist claims.

In the light of these reflections, territorial identity can be defined as a process of social construction, open and dynamic, through which the collectivities settled in a given territory choose the distinctive features of the territory they inhabit or where they act in, shaping shared values, solutions, actions, and future trends (Figure 1).

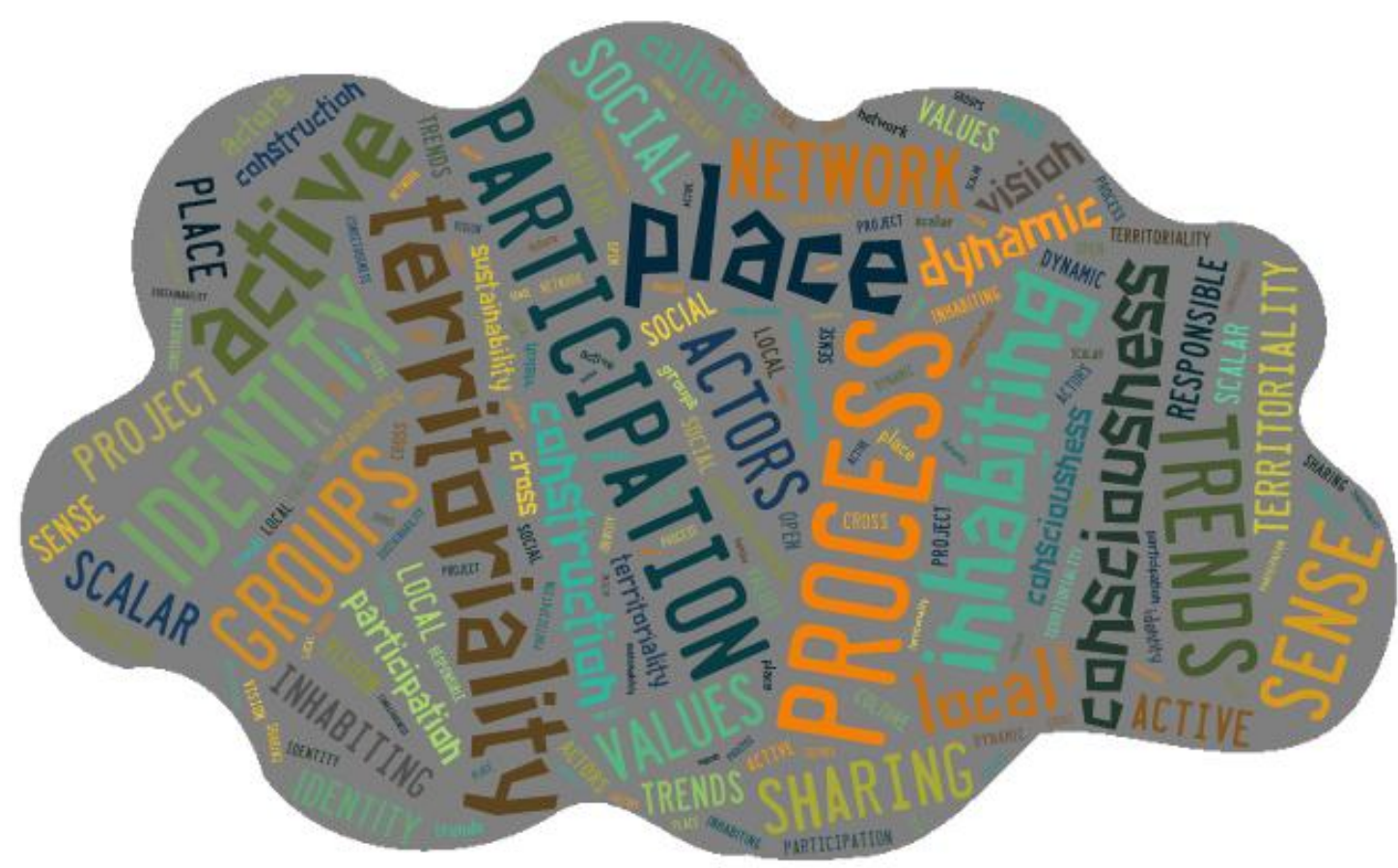

Figure 1: Tag cloud of local territorial identity in a French-Italian territorialist perspective (including the most frequent words used by the AGel group "Territorial Identities" in the publications realised until now) 
Territorial identity, in this sense, always refers to territorial connotations, but stressing compared to the traditional geographies of the past - its social, relational, open, dynamic, cross-scalar, and action-oriented nature. This means that territorial identity is not so much related to "who we are" and "where we come from", but above all to "what we want to become", as Stuart Hall (1996, p. 4) stated for cultural identities. For this reason, territorial identity can be considered a transversal social goal, an ongoing process of becoming rather than being, that involves all the social and cultural components of local territory, since it is centred on 'where we are', as a shared condition derived from inhabiting the same place, even if for a short time.

In a territorialist perspective, territorial identity can be considered as the outcome of a research-action process, a co-operative construction between researchers and local people, but also the condition for 'active territoriality' and contextualized, sustainable and participatory local development. In this sense, researchers can help local communities to define the territorial identity of the place they inhabit, but are local communities to choose which territorial features they consider relevant and meaningful, and whether to start a path of 'active territoriality'.

Considering its constructive, social, relational, and open connotation, local territorial identity cannot be studied only 'from above and the outside', on the basis of tangible and intangible aspects (landscape and urban forms, cultural and linguistic features, and so on), but through a complex and articulated field research, mainly with ethnographic methods, aimed at exploring representations and self-representations, local actors and relationship networks, strategies and practices, territorial ties and attitudes of local collectivities. Below, I will focus on representations and self-representation, postponing the discussion of other key topics on another occasion.

\section{KEY NOTIONS AND PRELIMINARY PITFALLS}

In order to overcome the risk of falling into the dichotomy between objective connotations and subjective perceptions - that still can be found in many geographic contributions - the research group has considered two concepts of Environmental Psychology: the identity of place, defined as "that part of personal identity that comes from dwelling in specific places" (Bonnes et al., 2009, p. 19); and the identity of the place, defined "on the basis of the most shared representations or images at the level of groups and communities related to the place in question" (Bonnes et al., 2009, p. 19). In this way, no taken for granted link of belonging is stated neither between place and its inhabitants (because subjects may have ties with more than one place, and not necessarily with the place they inhabit), nor between individual and collective identities (because subjects may do not share any cultural or social belonging in the place where they live).

We have preferred to employ these two notions of Environmental Psychology because of the ambiguity of sense of place in geographic literature, being a concept often referring to both the 'objective' connotations of a place and the 'subjective' feelings towards it (Foote \& Azaryahu, 2009). Likewise, it is frequent to find, also in the geographic literature, a sort of confusion between the various dimensions (personal, collective, social, cultural, ethnic, etc.) involved in identity discourses that certainly do not help the discipline to define its contribution to the scientific and political debate (cf. Debarbieux, 2006; Di Meo, 2016). On the contrary, the notions identity of place and identity of the place are both clearly based on 
subjective knowledge, viewpoints, opinions and experiences of a territory by its inhabitants, starting from the premise that every narrative on identity - at any scale - leans on a complex network of ideas, dialectics, histories, images, conditions, and relations (Paasi, 2003).

In this sense, the idea of the identity of the place looks very similar to what Raffestin stated about the concept of territoriality, intended as a complex of collective representative, imaginative and cognitive elements, which led the French/Swisse geographer to speak about territoriality in terms of "multidimensionality of the territorial experiences shared by the members of a collectivity" (Raffestin, 1988, p. 278).

For this reason, the identity of the place can be studied first of all through representations and self-representations: representations that is to say how the territory is told, described, portrayed in scientific papers, newspapers, movies, advertisements, pictures, novels, and so on, using textual analysis or visual methods as a tool; self-representations, that is, how the territory is narrated by local inhabitants and actors, which features are considered relevant and meaningful, using ethnographic methods (interviews, focus groups, participant observation, etc.). In this way, as Jenkins (1996, p. 20) stated, it is possible "to understand identity as a process, not an essence, continually remade through an 'internal-external dialectic' involving a simultaneous synthesis of internal self-definition and one's ascription by others".

As for the identity of place (or better, the identities of place), the aim is to understand subjective perceptions, feelings and attitudes towards both the territory people inhabit and the local collectivity, as well as the attitude towards insideness/outsideness/otherness, and the disposition towards an 'active territoriality', always through qualitative methods. This passage is even more necessary considering that, as Massey (1994, p. 167) noted: "there are very different ways in which reference to place can be used in the constitution of the identity of an individual", and that not always local territory corresponds to an idea of place as 'home', so as to provide a feeling of intimacy, well-being, and belonging.

The study of territorial identity implies also other preliminary pitfalls, such as the selection of the study area. In other terms, despite that the concepts of place and region have been deeply revisited, towards a relational, porous, unbounded, progressive, and cross-scalar conception (Massey \& Jess, 1995; Amin, 2004), a study on territorial identity must inevitably start from a 'where'. But which 'where'?

At a local scale, as above defined, territorial identity can be indeed studied in relation to an urban district, a historical small region, a rural area recognized for quality production (e.g. PDO - Protected Designation of Origin) or to any other demarked territory (e.g. gated communities or street gangs territories). But what about a rural/urban area that lacks such a clear and known demarcation? In other words, how to select which municipalities or streets should be considered in a study area? This is a focal question because to choose a study area may mean to assign an a priori identity to a territory and to implicitly address a research on territorial identity in that direction (De Rubertis, 2013). In both cases - defined and non-defined territories - perhaps it would be better to start from the perceptions of local population regarding the invisible boundaries that distinguish the territory where they live or act from others, using surveys, interviews, visual methods, or mental maps as a tool.

Another preliminary problematic question, at least in the territorialist perspective above delineated, concerns the issue of participation. Participatory processes are often mentioned as an example of full democracy and social justice, as a label that communicates: "this is what people say!" But is it really like that? A study on the case of Godo (Friuli-Venezia Giulia, North- 
Eastern Italy), for example, demonstrated that only middle-aged and older persons participated in the making of the local map of community, while immigrants and young generations self-excluded themselves (Bianchetti, 2013). Therefore, can that be considered a participatory process? A shared view of the identity of the place? In this sense, decisions undertaken by a few on behalf of everyone else risk to deny the philosophy that underlie participatory processes, engendering paradoxically new forms of social injustice and exclusions.

\section{CONCLUSIONS}

Territorial identity is often evoked in emergency situations, for example as a response of the local community to uncomfortable super-local decisions, but often it is too late. If every discourse on identity implies more or less explicit questions of power and policy goals (Di Meo, 2016), then it is better to work on territorial identity at a local scale, that is to say the sole spatial dimension where the physical proximity of the inhabitants (and the potential temporal continuity of their relationships) consents to configure territorial identity as a process of social construction, involving all the collectivities settled in a given territory.

Local communities engaged in and for the territory they inhabit are able to constantly build up territorial identity and to avoid decontextualized choices, or rather to prevent that homologation be fuelled by the undifferentiated, and hetero-directed localism (which is an oxymoron) would prevail over contextualized and participatory development (Giusti, 1998). Geographers and academic researchers in general can help local collectivities to build their territorial identities, as a first step towards relevant global goals.

Compared to other theoretical approaches, the French-Italian territorialist perspective give the possibility of reasoning both on the symbolic and operative aspects, as well as on the power relations between local and supra-local territorial actors (social, institutional, and economic actors), taking also into account - citing Di Meo (2016) - the key role that spatialized cultural elements play as symbolic territorial mediators.

In the territorialist perspective above delineated, participation plays a fundamental role in the implementation of territorial identity understood as 'active territoriality'. But in an age where people experience more easily a global cognitive proximity (thanks also to digital technologies) and a local physical distance (so that often we do not know our neighbour), participative processes require special attention and deepening.

The research group "Territorial Identities" of A.Ge.I. is now just working on participatory experiences - in progress and fulfilled, positive and negative, national and international, in urban and rural areas - in order to find out under which conditions and terms it is possible today to practice the idea of territorial identity as participative and 'active territoriality'.

\section{REFERENCES}

AGNEW, J.A. (1987). Place and Politics: The Geographical Mediation of State and Society. Boston, MA: Allen \& Unwin.

AMIN, A. (2004). Regions Unbound: Towards a New Politics of Place. Geografiska Annaler, 86(1), 33-44. 
ANTONSICH, M. (2014). Territorial Attachment in the Age of Globalization: The Case of Western Europe. European Urban and Regional Studies, 21(2), 206-221.

BANINI, T. (ed.) (2013). Identità territoriali. Questioni, metodi, esperienze a confronto. Milano: Franco Angeli.

BANINI, T., \& POLLICE, F. (eds.) (2015). Territorial Identity and Rural Development in the European Union. Semestrale di Studi e Ricerche di Geografia, 2, 7-16.

BIANCHETTI, A. (2013). Conoscersi, riconoscersi, rappresentarsi: le mappe di comunità. In Banini T. (ed.), Identità territoriali. Questioni, metodi, esperienze a confronto (pp. 76-91). Milano: Franco Angeli.

BONNES, M., BILOTTA, E., CARRUS, G., \& BONAIUTO, M. (2009). Spazio, luoghi e identità locali nelle tendenze recenti della psicologia ambientale. In Banini T. (ed.), Identità territoriali. Riflessioni in prospettiva interdisciplinare, Geotema, 37, 15-21.

CLARKE, S., \& KIRBY, A. (1990). In Search of the Corpse: The Mysterious Case of Local Politics. Urban Affairs Quarterly, 25, 389-412.

DE RUBERTIS, S. (2013). Identità territoriale e progetti di sviluppo. Un punto di vista cibernetico. In Banini T. (ed.), Identità territoriali. Questioni, metodi, esperienze a confronto (pp. 29-44). Milano: Franco Angeli.

DE WIT, C.W. (2012). Interviewing for Sense of Place. Journal of Cultural Geography, 30(1), 120-144.

DEBARBIEUX, B. (2006). Prendre position: réflexions sur les resources et les limites de la notion d'identité en géographie. L'Espace géographique, 35(4), 340-354.

DEMATTEIS, G., \& GOVERNA, F. (eds.) (2005). Territorialità, sviluppo locale, sostenibilità: il modello SLoT. Milano: Franco Angeli.

DI MÉO, G. (2016). Le Désarroi Identitaire. Une géographie sociale. Paris: L’Harmattan.

ELDEN, S. (2010). Land, Terrain, Territory. Progress in Human Geography, 34(6), 799-817.

FOOTE, K.E., \& AZARYAHU, M. (2009). Sense of Place. In Kitchin R., Thrift N. (eds.). International Encyclopedia of Human Geography (pp. 96-100). London: Elsevier.

GIUSTI, M. (1998). Locale, territorio, comunità. Appunti per un glossario. In Magnaghi A. (ed.), II territorio dell'abitare. Lo sviluppo locale come alternativa strategica (pp. 139-170). Milano: Franco Angeli.

GOVERNA, F. (2006). Risorse e potenzialità territoriali nella costruzione dell'azione collettiva. In Cavallo F. (ed.), Le risorse territoriali nello sviluppo locale (pp. 83-96). Firenze: Alinea Editrice.

GOVERNA, F., \& SALONE, C. (2004). Territories in Action, Territories for Action: The Territorial Dimension of Italian Local Development Policies. Journal of Urban and Regional Research, 28(4), 796-818.

GUERMOND, Y. (2006). L'identité territoriale: l'ambiguité d'un concept géographique. L'Espace Géographique, 35(4), 291-297.

HALL, S. (1996). Who Needs Identity? In Hall S., du Gay P. (eds.), Questions of Cultural Identity (pp. 1-17). London: Sage.

JENKINS, R. (1996). Social identity. London: Routledge.

LAW, J., \& MOL, A. (1994). Regions, Network and Fluids: Anemia and Social Topology. Social Studies of Science, 24(4), 641-671.

MAGNAGHI, A. (2010). Il progetto locale. Verso la coscienza di luogo. Torino: Bollati Boringhieri.

MASSEY, D. (1994). Space, Place, and Gender. Minneapolis: University of Minnesota Press.

MASSEY, D., \& JESS, P. (eds.) (1995). A Place in the World? Places, Cultures, and Globalization. Oxford: Oxford University Press. 
PAASI, A. (2003). Region and Place: Regional Identity in Question. Progress in Human Geography, 27(4), $475-485$

PAASI, A. (2009). The Resurgence of the 'Region' and 'Regional Identity': Theoretical Perspectives and Empirical Observations on Regional Dynamics in Europe. Review of International Studies, 35(S1), 121-146.

PAASI, A., \& METZGER, J. (2017). Foregrounding the Region. Regional Studies, 51(1), 19-30.

RAFFESTIN, C. (1980). Pour une géographie du pouvoir. Paris: Libraires Techniques.

RAFFESTIN, C. (1988). Repères pour une théorie de la territorialité humaine. In Dupuy G., Amar G., Barraque B. (eds.), Réseaux territoriaux (pp. 263-279). Caen: Paradigme.

TAYLOR, P.J. (1982). A Materialist Framework for Political Geography. Transactions of the Institute of British Geographers, 7, 15-34.

TURCO, A. (1988). Verso una teoria geografica della complessità. Milano: Franco Angeli. 